\title{
ON THE RULE OF LAW AND THE QUALITY OF THE LAW: REFLECTIONS OF THE CONSTITUTIONAL-TURNED- INTERNATIONAL JUDGE
}

\author{
EGIDIJUS KŪRIS \\ Judge of the European Court of Human Rights ${ }^{1}$
}

\section{SUMMARY}

I. Introduction. II. Towards the common concept of the rule of law. III. Quality of the law as a prerequisite for the rule of law. IV. By way of conclusion.

\section{INTRODUCTION}

As a judge, I have worn two hats: that of a constitutional judge (of the Lithuanian Constitutional Court) and that of an international human rights judge (of the European Court of Human Rights). These have been different judicial experiences.

A constitutional judge is concerned, first and foremost, with ensuring the supremacy of a constitution as the supreme law of the land. ${ }^{2}$ The raison d'etre of constitutional judicial review, in its original but enduring Kelsenian sense, lies in defending Grundnorm and legal order's hierarchy based on it. Constitutional courts ${ }^{3}$ are institutional means for ensuring that no act of lower legal force which is not concordant with

1 Former Justice (1999-2008) and President (2002-2008) of the Constitutional Court of the Republic of Lithuania; Professor of the Faculty of Law of Vilnius University. The views expressed in the article are solely those of the author; they do not represent the attitude of the Court.

2 In Lithuania, individual constitutional complaint has not been introduced yet (the last attempt having failed in 2017). The Constitutional Court therefore acts almost exclusively as the court of norms. I limit myself to this part of constitutional courts' competence, though in Europe many of them perform also other tasks, including the examination of constitutional complaints. Update-note after the submission of the article: A repeated attempt to introduce the constitutional complaint by means of a constitutional amendment has been undertaken in the fall of 2018; the process has not been completed yet.

3 For the sake of convenience, in this article the expression "constitutional courts" covers all courts which perform constitutional review of legal acts (irrespective of whether they are separate from courts of general jurisdiction or are part of their system), as well as equivalent bodies (such as constitutional councils exercising a priori review). The expressions "constitutional review" and "constitutional justice" also designate all types of judicial and equivalent review of constitutionality. 
Grundnorm remains valid law and, more generally, for ensuring the "abstract logical concordance between higher and lower legal acts". ${ }^{4}$ Law would not rule, unless it is ruled itself by Grundnorm; if it is, it is a quality law. This minimalist approach falls short of the prevailing belief that the rule of law encompasses much more than formal bierarchy and that, to be of quality, law must meet some substantive standards (quite so). But it is this minimum that necessitates and enables the protection of the legal order by means of constitutional review. What is consolidated in a constitution is secondary for that order itself. Constitutional courts have a formalist task to perform. As to the substance, they can perform different functions. Constitutional order is an attribute of any polity, not only a democracy. Rogue states also have constitutions. ${ }^{5}$ Alas, constitutional courts at times do yeoman service to dictatorships. ${ }^{6}$ Their existence per se does not ensure that the legal order will not only meet formal legality requirements, but also will be just (whatever that may mean). As of mid-2018, the World Conference on Constitutional Justice unites 112 constitutional courts. But rejoicing about membership numbers $^{7}$ must not outshine the fact that 2017 marked the $12^{\text {th }}$ consecutive year of decline in global freedom; ${ }^{8}$ the number of countries designated as free stands at 88 (45\% of 195 polities); ${ }^{9}$ only 77 polities (of 210 surveyed) are full or flawed democracies, and others hybrid or authoritarian regimes. ${ }^{10}$ The latter are quite amply represented in the World Conference. ${ }^{11}$

Some form of supervision of hierarchy, of which judicial review is the apex, is a sine qua non for a consistent legal order and, by extension, for the rule of law. Incoherent legal order, where legal acts deviate from Grundnorm, would be of no assistance for any substantive justice. Constitutional justice's formalist side thus must not be misprized. But

4 B. Zupančićc. "Constitutional Law and the Jurisprudence of the European Court of Human Rights: An Attempt at a Synthesis". Revus, 2003, no. 1, p. 58.

5 A joke has a circulation that even the jungle has a constitution, which consists of two articles: article 1 states that the lion is always right, and article 2 that if the lion is not right, see article 1 . This is what a perfectly minimalist constitution is, which encapsulates all three types of H. L. A. Hart's secondary rules. But a minimalist constitution is still a constitution.

6 See, e.g., T. Ginsburg, T. Moustafa. Rule by Law: The Politics of Courts in Authoritarian Regimes. New York: Cambridge University Press, 2008.

7 On the webpage of the European Commission for Democracy through Law (more known as the Venice Commission): World Conference of Constitutional Justice - 112 members! http://www.venice.coe.int/WebForms/ pages/?p=02_WCCJ\&lang=EN (accessed on 29 June 2018). Update-note after the submission of the article: One more member is expected to join as of 1 December 2018, (ibid.; accessed on 16 October 2018).

8 Assessment by Freedom House. Freedom in the World 2018: Democracy in Crisis. https://freedomhouse.org/ report/freedom-world/freedom-world-2018 (accessed on 29 June 2018).

9 Assessment by Freedom House. Freedom in the World 2018: Table of Country Scores. https://freedomhouse. org/report/freedom-world-2018-table-country-scores) (accessed on 29 June 2018). Of 47 member States of the Council of Europe eight are designated as partly free and 3 as not free.

10 Assessment by The Economist Intelligence Unit. Democracy Index 2017: Free Speech under Attack. http:// pages.eiu.com/rs/753-RIQ-438/images/Democracy_Index_2017. pdf?mkt_tok=eyJpIjoiWkRKbU1HWmxNVEUwTW1FdyIsInQiOiJPdlltVFV0blFRQzZNVERCZHhVeitZRElmUGplOHh3NWs1d2wzVzdRS1JvNU1kVmUxQVRESU9LbEVSOVwvR1F4aG1PV1N1S0ZZcng4NzBcLzVNZ09JOUxiZU5TTEVPekVHayttOTRqQkQ5TkNzWGNtRlowQTZ0UzlUK0pDdm9PVGlcLyJ9 (accessed on 29 June 2018). 20 polities are designated as full democracies, and 57 as flawed democracies. Of the surveyed (not all) member States of the Council of Europe, 14 are designated as full democracies, 18 as flawed democracies, 7 as hybrid regimes and 2 as authoritarian.

11 The next $\left(5^{\text {th }}\right)$ Congress of the World Conference will be held, in 2020, in the country designated in the above-cited rankings as not free and authoritarian. Note 7 supra. 
it must not be overestimated too. Hierarchy is not a goal of itself: constitutionalism is inherently linked to liberty, human rights and regime's legitimation. ${ }^{12}$

My other hat, i.e. my mission of the judge of the Strasbourg Court, is to contribute to the international protection of individuals' rights and freedoms ${ }^{13}$ enshrined in the European Convention on Human Rights and its Protocols. ${ }^{14}$ The Convention is a legal order different from a constitution (despite some similarities). It has been labelled as the "constitutional instrument of European public order". ${ }^{15}$ This functionalist utterance has inspired assertions that the Court should become, or already is, a "European constitutional court". ${ }^{16}$ The law of the Convention, as judicially enforced by the Court, indeed has a potential to constitute the substratum for a vital (and widening) segment of European public order; but even if one accepts that transnational constitutionalism is "desirable" and "emerges as entirely plausible" to "its nation-state counterpart", this does not imply that the Convention is a "transnational regime that can be persuasively characterised as constitutional and consistent with the ideal of constitutionalism", ${ }^{17}$ let alone that the Strasbourg Court is a constitutional court. Such equation would beg the question as to what constitution that constitutional court represents. The ability of the Convention to underlie part of European public order is of a different nature than the founding authority of constitution proper. The rationale of the latter lies in the same legal order's hierarchy based on Grundnorm; and that of the Convention in the High Parties' commitment to it as an international instrument, which fixes certain rights that comprise the core of the Parties' common legal heritage, with its accentuation of individual liberty, and merits international judicial protection. ${ }^{18}$ This falls short of formal hierarchy. The

12 "[W] conflate two norms when speaking of the rule of law. The first is that powers ... shall rule by, and themselves obey, enacted general rules, and that they shall change their policies by changing those rules rather than by arbitrary deviations for or against particular persons. The second is that there is a core of individual human rights inherent in law itself, so that the rule of law must include the protection of these rights." M. SHAPIRO. "Courts in Authoritarian Regimes". In: T. Ginsburg, T. Moustafa. Op. cit., note 6 supra, p. 329. "In liberal constitutional thought, the question of the rightness of the fundamental-legal regime is primary." N. DMitrijević. "Constitutional Democracy, or how to Prevent the Rule of the People". In: A. Sajó (ed.). Out and Into Authoritarian Law. The Hague: Kluwer, 2003, p. 79.

13 For the sake of convenience, in the ensuing narrative I omit "and freedoms".

14 Again, for the sake of convenience, I omit "and its Protocols".

15 Loizidou v. Turkey (preliminary objections) ([GC], no. 15318/89, § 75, 23 March 1995). This has been repeated in a number of judgments, the last ones (at the time of writing of this article) by the Grand Chamber being Avotinš̌ v. Latvia ([GC], no. 17502/07, §§ 101, 112 and 116, 23 May 2016) and Al-Dulimi and Montana Management Inc. v. Switzerland ([GC], no. 5809/08, § 145, 21 June 2016).

16 See, e.g.: G. Ulfstein. "The European Court of Human Rights as a Constitutional Court?”. PluriCourts Research Paper no. 14-08, 2014; P. Pinto de Albuquerque. "The Constitutionalisation of the Legal Order of the Council of Europe”. In: I. Motoc, P. Pinto de Albuquerque, K. Wojtyczek (eds). New Developments in Constitutional Law: Essays in Honour of András Sajó. The Hague: Eleven, 2018.

17 M. Rosenfeld. "Transnational Constitutionalism and Legal Cultural Pluralism”. In: I. Motoc, P. Pinto de Albuquerque, K. Wojtyczek (eds). Op. cit., note 16 supra, pp. 383, 386-388.

18 The question, however, remains as to what is common in that heritage. The wider the variety of legal institutions, the less commonness can be expected to be found (especially in view of the divergence between the continental and the Anglo-Saxon legal traditions, but also of very different historical experiences of many continental countries). It is tempting to reduce the search for commonness to the sphere of constitutionalism and to see its core in the two principles: free elections and constitutional protection of fundamental rights elements (see, e.g., D. RousSEAU. "The Concept of European Constitutional Heritage". In: The Constitutional Heritage of Europe. Strasbourg: Council of Europe Publishing, 1997, p. 21). But such approach can be countered by pointing to the fact that several member States of the Council of Europe are not free, hybrid regimes or authoritarian (notes 9 and 10 supra), as well 
Convention is not a constitution of any kind, unless this concept becomes inflated. What is more, although the Court is entitled to find, by a binding judgment, violations of the Convention, it has no authority to invalidate domestic legislation, on which practices constituting these violations are based. Not being a negative legislator, ${ }^{19}$ it does not satisfy the minimal condition for being a constitutional court. Notwithstanding that, one must admit that the ceaseless insistence on the Court's equation with constitutional courts has rendered this belief almost fait accompli; ${ }^{20}$ analytical objections to it are less and less taken into account.

Like constitutional courts, born from the need to ensure the hierarchy of the legal order, are no panacea for ensuring that law reigns, for a court being not a constitutional court is no fault in the eyes of the rule of law. The fact that the Strasbourg Court is not a constitutional court in no way abates its possibilities to positively impact on the quality of the law and, consequently, its role of the guardian and promoter of the rule of law.

\section{TOWARDS THE COMMON CONCEPT OF THE RULE OF LAW}

In about mid-12th century the development of law in the West produced an unprecedented phenomenon: Western legal tradition, identified by the following traits: legal institutions are analytically distinct and autonomous from (though influenced by) other types of institutions (religion, politics, morality, custom); law is administered by a corps of people, engaged in legal activity on a professional basis as a more or less fulltime occupation; legal institutions, which would otherwise be disparate and unorganised, are conceptualised and systematised through meta-law, as elaborated in learned treatises and classrooms of law schools, which allows for their analysis and evaluation; law is conceived to be an integrated system (corpus juris), whose vitality is ensured by the belief in its ongoing character and capacity for organic change, subject to its internal logic, requiring that it changes not adapting at random to new conditions, but responding to an inner necessity for reflection and reinterpretation of the past to meet future needs; diverse jurisdictions co-exist and compete within the same community, and this renders the tradition pluralist; law is supreme over political authorities, as the latter may make law, but may not make it arbitrarily, and until law has been remade, they are bound by it; the perennial tension between the ideals and realities has periodically led to violent overthrows of the existing legal systems by revolution, but they resulted in the tradition becoming even stronger. ${ }^{21}$ The idea of supremacy of law over political (and other) authorities (and the idea of human rights too) has evolved out of the Western legal

as to the fact that so-called Eastern and Western judges of the Strasbourg Court have brought a "different perception to human rights" (N.-L. AROLD. The Legal Culture of the European Court of Human Rights. Leiden/Boston: Martinus Nijhoff Publishers, 2007, p. 69 et seq.).

19 Constitutional courts are necessarily Kelsenian negative legislators. This prerequisite, however, does not prevent the rising trend of them acting as de facto positive legislators too. A. R. BREWER-CARÍAs. Constitutional Courts as Positive Legislators: A Comparative Law Study. New York: Cambridge University Press, 2011.

20 B. Zupančić. Op. cit., note 4 supra, p. 59.

21 Here I refer, in a truncated form, to H. J. Berman, the unsurpassed authority in this field of research, who in the 1960 s coined the very term "Western legal tradition", and in particular to his magnum opus: H. J. BERMAN. Law and Revolution: The Formation of the Western Legal Tradition. Cambridge MA/London, 1983. 
tradition..$^{22}$ This idea is the starting point for understanding what is referred to as the rule of law.

Through the colonisation of the rest of the world the West imposed its institutions on other civilisations, which (even if having undergone certain transformations) became widely assimilated. Those other civilisations absorbed the view that law is an integrated system and that it is superior to political authorities. The rule of law has become an official parlance even in those polities, where it is only a façade. Dictatorships' resort to such camouflage also signifies the idea's moral strength. Mention should also be made of international law, which (though often blatantly disregarded) is crucial for holding international relations harmonious. The Western legal tradition is a factor promoting international integration and globalisation, inter alia, via the United Nations or such regional formations as the European Union or the Council of Europe. ${ }^{23}$

It has been asserted that the Western legal tradition is facing a crisis, as only a few (even a minority) of its above-mentioned traits have been still truly inherent in the Western law, namely: relative autonomy; cultivation by legal professionals; flourishing of law training centres; and development of meta-law. Other traits allegedly have been affected by erosion: law has been less and less conceived as a coherent whole (with an inherent hierarchy of its sources); its growth through reinterpretation has been increasingly held to be an ideological illusion; changes in law have been viewed as resulting not from the internal logic of its growth, but rather due to the pressure of outside forces; the view that law is superior to politics has yielded to the view that it is mere means of effectuating the will of those exercising political authority; the pluralism of law has been considerably weakened by the tendency "to swallow up all the diverse jurisdictions and systems in a single central program of legislation and administrative regulation"; the belief that the Western legal tradition precedes and survives the great total upheavals and thus transcends revolution has been challenged by the belief that law is wholly subordinate to revolution and that even if the old forms are retained, they are "filled with new content". All this has been accompanied by contempt for and cynicism about law, revolt against legal formalism, yielding to public policy needs, and fairness as a legal category losing its historical and philosophical roots being "blown about by every wind of fashionable doctrine". ${ }^{24}$ The crisis of the Western legal tradition would mean also the crisis of the rule of law. No one could predict what might come after the rule of law.

22 Berman contended that perhaps the earliest published use of the English expression "rule of law" in the sense of "reign of law" was in 1649 by King Charles I during his defence in the Parliament: "power reigns without rule of law". More than two centuries later it was brought into widespread use by A. V. Dicey. H. J. BERMAN. "The Rule of Law and the Law-Based State (Rechtsstaat): With Special Reference to the Developments in the Soviet Union". The Harriman Institute Forum, 1991, vol. 4, no. 5, p. 2.

23 See, e.g.: D. B. Goldman. Globalisation and the Western Legal Tradition: Recurring Patterns of Law and Authority. Cambridge: Cambridge University Press, 2008; G. Teubner (ed.). Global Law without a State. Aldershot/ Brookfield VT: Dartmouth, 1997; TwINING, W. Globalisation and Legal Scholarship. Nijmegen: Wolf Legal Publishers, 2011.

24 Berman, H. J. Law and Revolution, note 21 supra, pp. 37-41. Two decades later Berman argued that a new legal tradition, which he called "the world legal tradition", was in its formative stages. In his opinion, this new tradition was bringing together the diverse legal traditions of various cultures of the world, combining the Western legal tradition with that of other cultures, and challenging all of them. ID. "The Western Legal Tradition in a Millenial Perspective: Past and Future". Louisiana Law Review, 2000, vol. 60, no. 3. That article was published a year before what has become known as $9 / 11$. In one of his last works Berman claimed that the Western legal tradition 
There are many indications that this apocalyptic scenario is not trivial: economic crises, democracy deficit, use of popular vote and technologies for undermining the authority of law, populism, radicalism, xenophobia, international conflicts which look like harbingers of the Huntingtonian clash of civilizations. They all - each in its own way and combined with the rejection of the hierarchical structure of law, quasi-legal instruments' competition with hard law, fragmentation of international law, and ineffectiveness of international organisation - challenge the traditional role of law both in societies and among them and herald the troubles that the rule of law is likely to undergo both as a principle underlying legal systems and as a general idea. One of the aspects of the crisis is the tension between the expectations, laid down in law and protected as rights, and public authorities' inability (or unwillingness) to fulfil their commitment to ensure these rights. Rights are thought to be trumps, ${ }^{25}$ but today's deck of cards has too many jokers attempting to trump them.

Courts, by their nature, impede the undermining of the role of law. Not reducing themselves to legislator's mouthpiece, they are portrayed as inherently activist and tagged as "courtocracy", "juristocracy", "constitutional theocracy", or "dictatorship of black robes". ${ }^{26}$ The societal support for this demonising attitude is not inconsiderable and has intensified since when the ominous insights about the crisis of the Western legal tradition were pronounced in the 1970s. But the pessimistic prophecies are not shared by many. Notwithstanding its difficulties, that tradition has a potential of resistance to the endeavours to subjugate law to politics or societal pressure. The concerns about the crisis were voiced before the breakup of the USSR, which was creating an alternative legal tradition, which was capable of playing some role in shattering the foundations of its Western competitor, but collapsed itself; and before the advent of EU, whose law co-exists and competes with member States' national and various supranational legal systems. Resistance potential may also be evoked by the need to withstand the challenges of new major international conflicts. More generally, the direction and magnitude of the formation and transformation (and demise) of traditions may be reflected on with some certainty only from time's perspective. Although the indications of the crisis must not be oversimplified, any conclusions should be based not so much on the quantifiable factography of manifestations of the neglect of law (e.g., assaults on individual liberty), oft-generalised as "the submission of law to politics", "legal cynicism", or "displacement of legal formalism", but on the fundamental changes in societies' belief as to the working of law and its role vis-à-vis other institutions. If the Western legal tradition is in crisis, the latter would be a phenomenon not of formal legality, but of culture.

Lastly, a crisis per se does not imply a collapse. The rule of law is not always holding the field against all sorts of attacks; however, its very idea has not been abandoned, at least

was "no longer alive and well". ID. Law and Revolution II: The Impact of the Protestant Reformations on the Western Legal Tradition. Cambridge MA: Harvard University Press, 2003, p. 282.

25 Dworkin, R. "Rights as Trumps". In: J. Waldron (ed.). Theories of Rights. Oxford: Oxford University Press, 1984 .

26 In the article with an emblematic title, one author argues that the notion of the rule of law has been changed, inter alia, by transforming the object of legitimacy from a question of power (what the rules do) to a question of authority (who appoints the ruler) and by making it equivalent to procedural correctness (one of the the key words being judiciary's independence), thereby reinforcing the role of the judiciary. E. Colombatto. "It Was the Rule of Law. Will It be the Rule of Judges?”. Revue économique, 2007, vol. 58, no. 6. 
not yet. While it is completely possible that the Western legal tradition will undergo essential transformation, it is also possible that it will revive and strengthen, like after previous major upheavals, and "instead of [its] prophesied end ... we will see only the beginning of a new stage in its development". ${ }^{27}$ Unless this transformation throws overboard the rule of law, the tradition will persist. Courts, both national and international, play a crucial role in this - also by filling the idea of the rule of law with concrete contents.

"Rule of law" is translated to German as Rechtsstaat and to French as État de droit, i.e. law-governed (or law-based) state. On the continent, an equivalent of the German/ French term is used in many languages. These are not mere lingual peculiarities. ${ }^{28}$ The two concepts have common elements, but are not identical. Rechtsstaat is incident to continental Europe (and countries that have taken over the logic and culture of continental law) and is said to comprise the minimum of the rule of law and thus to be a narrower concept. It implies that the sovereign is bound by law as long as it has not been changed, but is not precluded from changing even its cornerstones. The autonomy of law from politics thus depends on political authorities' will and/or ability to change the foundations of law. In a democracy, this autonomy may be overridden, if authorities' intention to make a change is supported or even urged by the electorate.

The Anglo-Saxon concept of the rule of law (typical of Britain and countries that have taken over her legal experience) does not allow even the sovereign to intervene in the law as he wishes. Some rights are considered inalienable and override his will, even where it reflects general consensus. This implies some higher standards, not lending themselves to intervention initiated by political authority or spurred by societal pressure. They emanate not from positive law as law-makers' will, but from a competing source, whatever it may be: religion, morality, human nature, perception of justice, nation's spirit etc. Since they limit law-makers' discretion, they must themselves be part of law, although not that posited by legislator, i.e. not positive law. Legal philosophies diverge as to the nature of these standards; not entering into this debate, it must be said that law-makers' arbitrariness has not been advocated even by positivism, which does not agree that these standards are of legal nature: while accepting no legal restrictions on the sovereign's law-making power, it makes no attempt to justify immoral or unfair law. Its Kelsenian version holds that Rechtsstaat is a tautology, because a state is able of expressing its will only in the form of law, hence, any state is governed by law; but this analysis is not meant to comfort legal practices of regimes professing contempt for moral precepts, including those which would fetter law-makers' will and render it not law.

The geographical dimension of the rule of law-Rechtsstaat divide, manifesting the difference between the Anglo-Saxon and the continental viewpoints, must not be overrated. In the British tradition legislator-made law has a competitor in the body of law, made by courts in the course of application of not only laws, but also concepts of justice, customs, and general principles of law, not set in laws and even overriding them. But positivism anchored itself in legal thought due to thinkers cultivated in namely that

27 Machovenko, J. Teises istorija (Legal History). Vilnius: Registrų centras, 2013, p. 33.

28 Cf. Venice Commission's Report on the Rule of Law, 25-26 March 2011, CDL-AD (2011) 003rev. See (also on the differences within the Anglo-Saxon and the continental concepts), e.g., E. O. Wennerström. The Rule of Law and the European Union. Uppsala: Iustus Förlag, 2007, p. 61 et seq. 
tradition, such as Jeremy Bentham, John Austin, or H. L. A. Hart. Also, in $19^{\text {th }}$ century the United States Supreme Court invoked the procedural potential of constitutionalism and assumed the role of constitutional court. Hans Kelsen, the European mover of constitutional courts as a sub-branch of the judiciary, had rationalised what already existed, in a different institutional setting, outside the continental tradition. ${ }^{29} \mathrm{His}$ model, in which constitutional courts can override legislators' enactments, was taken over by many polities in, but also outside Europe. Also, some of the strongest criticisms of the real state of law and its claims to reign originated not in legal cultures once comfortable with positivism and Rechtsstaat, rather than the broader meaning of the rule of law, but in the Anglo-Saxon world. In the 1970s the United States begot the pretentious Critical Legal Studies Movement, which not only vividly portrays inconsistencies of law as it is (the force of many of their assessments must be admitted), but also tends to trumpet these criticisms into a generalised repudiation of law as a mere offspring of power (politics, religion, ideology etc.) and thus to nothing more than a deceit, which must be deconstructed, dethroned, "thrashed". While this negativist attitude was gaining momentum in the United States, Europe underwent new inflows of constitutional justice.

Nowadays, the divide discussed here has diminished in importance. The two concepts are still distinguished analytically, but they have converged both at the level of ideas and in the real operation of law. Rechtsstaat has been interpreted in an increasingly expansive manner to require that legislators abide by such tenets as inalienability of human rights and good governance, implying substantive and procedural requirements for law-making, even if not fixed in any statute. To counteract the positivist concern that such tenets could be legally binding, only if they themselves are of legal nature, constitutional courts have detected them in constitutions. For all practical purposes, the criteria of lawfulness of positive law thus no longer stem from some difficult-to-grasp supra-legal realm (on whose nature and mode of imposition on the positive law a debate will go on till doomsday), but from a constitution - a Rousseaesque contrat social with its connotation of natural justice, but also the supreme act of positive law. The detection has been easy where a constitution explicitly mentions the rule of law (or law-governed state); but courts have not shied away from it also where there is no such mentioning, their task being relieved by the fact that many requirements directly enshrined in modern constitutions have clear rule of law connotations and lend themselves to interpretation as its instances, such as prospectivity and accessibility of law; access to justice before independent and impartial courts; equality before the law; respect for human rights; compliance with international law etc. Attribution of legal nature to the rule of law marks the passage from formalist to substantive constitutionalism, and from constitution's letter to spirit. The latter term of art, despite its arcane naming, is a worldly, operational concept, which courts have interpreted with sufficient concreteness. Letter still matters, but yields to spirit; formalism has not been rejected, but rules do not reign over principles. Constitutional justice thus has contributed tangibly to Rechtsstaat's approximation to the rule of law and, more generally, to conceiving law as not an axiomatic, but a jurisprudential, arguable phenomenon, which is not confined to what has been determined by legislator, but embraces judge-made law and progresses through application

29 A. R. Brewer-CARÍAs. Op. cit., note 19 supra, p. 9. 
of concepts of justice and general principles of law, conceptualised in legal thought (but not necessarily mentioned in laws). It is said that the constitution is what judges say it is; in a similar vein, the rule of law is what courts say it is. This is a descriptive, not prescriptive statement; realism, not positivism. And the reality is that whereas in a national legal system one (constitutional) court resolves what the constitution of that country is, the rule of law is a shared idea, not monopolised by any single legal order and interpreted in parallel by many national and international courts. None of them has the final say: they all contribute to revealing and advancing the contents of this concept.

There rub is: how to reconcile an arguable character of law and the rule of law? ${ }^{30}$ As said above, courts are no panacea for ensuring the reign of law. There have been prevaricating, cowardly or simply unfair judicial decisions in many jurisdictions, korematsus, ${ }^{31}$ which courts, with hindsight, would like to see deleted from their history. How can one ensure that the judicial interpretation of law is transparent and not arbitrary? Courts' authority to determine the meaning of the rule of law per se does not imply that what they argue about it tallies with its intrinsic meaning, i.e. that that meaning, formal obeisance to the rule of law being made, is not distorted on political orders, under societal pressure, or even on a whim. Their authority to determine the meaning of the rule of law signifies, in practice, that meaning's advantage over all others, whoever their authors may be (even sovereigns), and disregarding that, prior to courts' interpreting anew some element of the rule of law, there might have prevailed its alternative perception, underlying respective practices and even approved by courts themselves. For a realist, this implies that courts are in fact superior to the rule of law itself. The latter would be difficult to validate in normative (legal or moral) terms and would pour water on the mill of "courtocracy". On the other hand, if there may be an intrinsic meaning of the rule of law superior to what courts may have erroneously interpreted, this would render that meaning mystical, devoid of that tangibility which already has been imparted on it by the collective working of courts.

The arsenal of safeguards against the judicial distortion of the hypothetical intrinsic meaning of the rule of law is meagre. In Europe one such safeguard against its distortion by national courts might be the Strasbourg Court, which, as an international body, is thought to be less prone to some of the pressures and more apt than domestic courts to interpret the rule of law in the light of common legal and cultural heritage (the fact that it is not financially independent is almost never discussed). However, this safeguard is not cast-iron, as there is no guarantee that the Strasbourg Court will not itself distort the intrinsic meaning of rule of law.

The relation between the meaning of the rule of law and its judicial interpretation is not the one of supremacy, but of the moral legitimacy of courts' decisions. ${ }^{32}$ Questioning that

30 N. MacCormick. Rhetoric and the Rule of Law: A Theory of Legal Reasoning. Oxford: Oxford University Press, 2010, pp. 14-16.

31 I refer, in the appellative sense, to Korematsu v. United States (323 U.S. 214 (1944)), the US Supreme Court case concerning the constitutionality of the executive order, which called for internment of Americans of Japanese ancestry during World War II, regardless of citizenship. The Supreme Court by 6 votes to 3 upheld the order as constitutional.

32 K. E. Himma. "What Exactly is the Problem with Judicial Supremacy?" The Rule of Law, Moral Legitimacy, and the Construction of Constitutional Law. In: M. Jovanović, K. E. Himma (eds.). Courts, Interpretation, the Rule of Law. The Hague: Eleven, 2014, pp. 18-32. 
legitimacy may lead us out from world of law back to the initial aporia of the nature of the highest criteria of lawfulness of positive law (which courts have overcome by adopting the view that these criteria are to be found in constitutions). This risk is pragmatically avoided by realistically accepting (regardless of how one views realism as a methodology) that the meaning of the rule of law is determined by courts, and if they err, their moral critique cannot be rebutted as illegitimate on the sole ground that it rests on non-legal bedrock. Justice is not limited to justice under law (after all, most people are not lawyers, but seek justice). Justice is an essentially contested concept. ${ }^{33}$ Intellectual exercise in revealing the allegedly true essence of such concepts is thought-stimulating. But all efforts to shell out the practicable meaning of the rule of law, other than the one laid down in judicial doctrines, so far have not abandoned the realm of speculation. If there are theoreticians who can square this circle convincingly and authoritatively (and not only with full inner confidence), I have not met any. "Rule of law" is a term of art, for which no one has been able of giving a single comprehensive definition. ${ }^{34}$

"Rule of law" allegedly has become a hurrah-word, exploited by all sorts of radicals, centre liberals and conservatives. ${ }^{35}$ It may be employed for criticising virtually any policy or legal practice. Billpostings of indications of defiance of law (they can be recorded in any state) are used for claiming that a state is not governed by law. The rule of law thereby turns into a rhetorical cliché instrumentalised in political struggle. But ideals, as per definition, are not achievable. The rule of law is not attainable in its perfection. Deviation of legal practices from its standards does not, in itself, warrant a generalised labelling of a state as not being governed by law. The notion of the rule of law is meant not to define an ideal, but to provide guidelines for improvements based on the assessment of concrete defects. Whether a case meets the standards of the rule of law and, more broadly, whether a state is governed by law, rests on the well-known formula "I know it when I see it", where the criterion of divide is the contrast between the rule of law and arbitrary power. ${ }^{36}$ It thus suffices to verify the few main themes of the latter: government limited by law; formal legality; and the rule of law, not man. ${ }^{37}$ This open-ended description calls for specification - which, however, is encumbered by the conceptual divide between Rechtsstaat's formalism and the substantivity of the broader meaning of the rule of law.

The two approaches focus on, respectively, the form of positive law and its substance. The gist of the formalist theories is that the rule of law means "literally what it says", i.e.

33 In the sense from the outset attributed to this category. See W. B. GaLliE. "Essentially Contested Concepts". Proceedings of the Aristotelian Society, 1956, vol. 56, issue 1. On "justice" and "rule of law" as essentially contested concepts see, e.g., D. Collier, F. Daniel, A. O. Maciuseanu. "Essentially Contested Concepts: Debates and Applications". Journal of Political Ideologies, 2006, vol. 11, no. 3.

34 D. M. BeatTy. The Ultimate Rule of Law. Oxford: Oxford University Press, 2004, p. vi.

35 C. SAmpFord. Retrospectivity and the Rule of Law. Oxford: Oxford University Press, 2006, p. 39.

36 M. Krygier. "False Dichotomies, True Perplexities, and the Rule of Law". In: A. Sajó (ed.). Human Rights with Modesty: The Problem of Universalism, Leiden/Boston: Martinus Nijhoff Publishers, 2004, pp. 255-256. Here is another example of "simple" definition of the rule of law by the same author: "At a bare minimum, the point of the rule of law ... is relatively simple: all actors should be constrained by, and people should be able to rely on, the law when they act." ID. "The Quality of Civility: Post-Anti-Communist Thoughts on Civil Society and the Rule of Law”. In A. Sajó (ed.). Out and into Authoritarian Law, note 12 supra, p. 249.

37 B. Tamanaha. On the Rule of Law: History, Politics, Theory. Cambridge: Cambridge University Press, 2004, pp. 114-126. 
"the rule of the law", ${ }^{38}$ or even that "the rule of law is a law of rules". ${ }^{39}$ Such utterings, witty though they seem, are trite. There cannot be a rule of law without rules of law, and only law consisting of rules can be certain and predictable. ${ }^{40}$ Substantivist theories assert that, in order there to be the rule of law, law should establish (social) justice, including "fair" distribution of public goods. To define the rule of law, already a problematic notion, they import several other essentially contested concepts: "justice", "fairness" and "public goods". This only complicates the matter.

Both camps further differentiate into thin(ner) and thick(er) theories. ${ }^{41}$ The thin ones are more functional and procedural; the thick ones more substantive. ${ }^{42}$ What for the thin theories is "rule-by-law", for the thick ones "individual rights". Moving in the direction of greater thickness of both types of theories, the same goes for "formal legality" and "right of dignity and/or justice"; and "democracy + legality" and "social welfare". ${ }^{43}$ The most extreme of the thick theories equate law-governed state with social/welfare state, thereby leaching out the rule of law of its legal core and rendering it an ideological parlance. Yet, the rule of law "cannot be about everything good that people desire from government". ${ }^{44}$ This would imply that states encountering major economic difficulties may not be treated as being governed by law, because they are unable of ensuring welfare. Law-governed state's fusion with social/welfare state would render the Strasbourg Court's case-law on standards of the rule of law (in particular regarding non-derogable rights) in times of crises $^{45}$ irrational. Also, economy may develop fast, and welfare may be ensured under dictatorial regimes too. Although the importance of the rule of law is recognised for virtually all areas of life, including economic progress, the significance of law for economics should not be exaggerated. Even less it is permissible to equate the rule of law and economic progress (welfare). ${ }^{46}$ Like legal formalism per se is not the necessary, let alone determining part of social insensitivity, social justice programmes are to be assessed on their own merits, to which legal argument may bring only some extra savour.

It is tempting to derive the rule of law-Rechtsstaat divide (and their differentiation into thin and thick theories) from the antagonism between positivism and natural law theory. In fact, that divide does not prevent the two great theories from meeting on the field of the rule of law. Some positivists (Friedrich von Hayek, Joseph $\mathrm{Raz}$ ) are deemed as "moralising" for attribution to the rule of law of certain moral principles. It thus makes sense to classify as thick and thin not all theories, but only

38 J. Raz. "The Rule of Law and Its Virtue”. Law Quarterly Review, 1977, vol. 93, no. 1, p. 196.

39 A. SCALIA. "The Rule of Law as a Law of Rules". University of Chicago Law Review, 1989, vol. 56, no. 3, p. 1175

40 N. MacCormick, N. Op. cit., note 30 supra, p. 12.

41 C. SAmpford. Op. cit., note 35 supra, pp. 45-55. For more on this divide see: S. Kirchin. (ed.). Thick Concepts. Oxford: Oxford University Press, 2013; B. Williams. Moral Luck, Cambridge: Cambridge University Press, 1985. On the application of this distinction to the notion of the rule of law, see: A. Hutchinson, P. MonAHAN. The Rule of Law: Ideal or Ideology. Toronto: Carswell, 1987, p. 101.

42 K. E. Himma. Op. cit., note 30 supra, pp. 13-18.

43 B. Tamanaha. Op. cit., note 37 supra, pp. 91-113.

44 Ibid., p. 113.

45 See, e.g., L.-A. Sicilianos. "The European Court of Human Rights at Time of Crisis in Europe". European Human Rights Law Review, 2016, issue 2.

46 F. K. Upham. "The Illusory Promise of the Rule of Law”. In: A. Sajó (ed.). Human Rights with Modesty, note 36 supra, p. 279. 
those that moralise ${ }^{47}$ for those which do not assert any moral principles and completely detach law from morals (like Kelsen's normativism) are so thin that, for the purposes of postulating the elements of the rule of law, they are devoid of potential. The remaining thin and thick theories from both camps recognise the significance of human rights, which renders their opposition relative. And the elements of the rule of law that positivism is armed with have been worked out by Lon L. Fuller, a protagonist of natural law.

Fuller asked: when would it be possible to hold that there is no rule of law in a hypothetical state governed by a monarch? and came up with the answer, that it would be so, if that monarch:

i) tries to make special rules for everyone to suit their particular needs, but this only arouses confusion and anger at differential treatment;

ii) fails to publicise them, so nobody knows what laws to follow;

iii) makes all his laws retroactive;

iv) enacts vague or obscure rules;

v) enacts rules that contradict each other;

vi) enacts rules that could not be followed;

vii) fails to apply rules consistently;

viii) changes his laws so often that his subjects cannot rely on them to plan their actions. ${ }^{48}$

Such law would be immoral. The reverse are the standards of the rule of law, or its elements. Their necessity springs from the internal morality of law.

Abundant theorisings about the standards of the rule of law and constructs of the rule of law as an operational category, whatever their merits, often are but variations of Fuller's sketch. ${ }^{49}$ According to Tom Bingham, the rule of law must satisfy the following prerequisites (“ingredients”):

i) law (including judge-made law) must be accessible, predictable, as far as possible intelligible and clear;

ii) discretion has to be limited in that sense that questions of rights should be resolved by the application of law and not by the exercise of discretion;

iii) persons have to be equal before the law, and differentiated legal regulation allowed only if objective differences so require;

iv) public officials must exercise their powers in good faith, fairly, only for the purpose for which these powers were conferred, without exceeding their limit, and not unreasonably;

v) human rights must be respected;

vi) means must be provided to resolve, without prohibitive cost or inordinate delay, bona fide disputes;

47 M. Neumann. "The Rule of Law: Politicizing Ethics”. Aldershot: Ashgate, 2002, pp. 2-3.

48 L. L. Fuller. The Morality of Law (rev edn). New Haven CT: Yale University Press, 1964.

49 See, e.g.: A. Marmor. "The Rule of Law and Its Limits". Law and Philosophy, 2004, vol. 23, no. 1; M. J. Radin. "Reconsidering the Rule of Law”. Boston University Law review, 1989, vol. 69, no. 4; J. Raz. The Authority of Law: Essays on Law and Morality ( $2^{\text {nd }}$ edn). Oxford: Oxford University Press, 2009. 
vii) fair trial must be guaranteed;

viii) compliance with international law should be ensured. ${ }^{50}$

These elements, conceptualised in theory, are present in modern constitutions (often along with the explicit mentioning of the rule of law). They have been consolidated in the Venice Commission's 2011 Report on the Rule of Law, ${ }^{51}$ which attempts to reconcile different notions of the rule of law. Bingham's list of eight "ingredients" has been reworked and reduced to six:

i) legality, including a transparent, accountable and democratic process for enacting law;

ii) legal certainty;

iii) prohibition of arbitrariness;

iv) access to justice before independent and impartial courts, including judicial review of administrative acts;

v) respect for human rights;

vi) non-discrimination and equality before the law.

Notwithstanding its merits, the list is debatable. In particular, the fifth "ingredient" overlaps with all others. Distinguishing legality as a separate "ingredient" is also misleading, because legality rightly is the central element of the rule of law ${ }^{52}$ and thus must be considered as an inherent dimension of all other "ingredients". For instance, what lacks legal certainty or is arbitrary should not be considered as lawful and thus as "legal". On that account, Fuller's eight elements (and Bingham's eight "ingredients") can be presented in the following way:

i) generality (there must be rules which are "more than patternless exercises of political power);

ii) promulgation of laws;

iii) prohibition of retroactivity (with some exceptions aimed at interpretation or curing irregularities of form);

iv) clarity (sufficient precision);

v) absence of conflicting provisions;

vi) not requiring impossible;

vii) stability (changes must be not frequent);

viii) congruence between official acts and declared rules. ${ }^{53}$

But the Report, as soft law, was not meant to please an academic taste. It is geared to practical needs: to reinforce the notion of the rule of law as an operational category, to provide guidelines for legislation and law-application, and to facilitate judicial

50 Bingham, T. The Rule of Law. London: Penguin Books, 2010.

51 Note 28 supra.

52 Lautenbach, G. The Concept of the Rule of Law and the European Court of Human Rights. Oxford: Oxford University Press, 2013, p. 37 et seq.

53 Ibid., pp. 38-39. 
application of the standards of the rule of law. Although unfolding the substance of the rule of law, as a constitutional concept, is the task of constitutional courts, none of them is fully free in this activity: they must take account of the shared idea of the rule of law as part of common heritage.

The above-indicated standards are subject to fine-tuning. Let us, by way of example, have a closer look at one of the "ingredients": the prospectivity of law (inherently related to its predictability and legal certainty). As a matter of principle, retroactive legislation may be held to be not law at all, because it is factually not possible to regulate the past. But prospectivity is not superior to other standards of the rule of law; it must not create an illusion that perfect predictability of law is achievable. ${ }^{54}$ For example, Article 7 of the Convention prohibits retroactive legislation in rather absolute terms in the context of criminal proceedings, but allows for an exception: this prohibition "shall not prejudice the trial and punishment of any person for any act or omission which, at the time when it was committed, was criminal according to the general principles of law recognised by civilised nations". The imperative of prospectivity must be accommodated to real-life situations, where blind toothing to the letter of law may bring about the dysfunction of the whole system. Pereat mundus, flat iustitia; but what is iustitia worth, if mundus periit? When faced with major crises, authorities resort to retroactive (retrospective) law-making; they do this also for the benefit of the addressees of prior legislation. To provide one example, the Strasbourg Court dismisses applications on the ground that retroactive legislation has been introduced, providing for new domestic remedies that must be exhausted before applying to this Court,${ }^{55}$ or domestic courts have interpreted the old law anew so that it is now deemed as providing such remedies. ${ }^{56}$ Justifiable deviations from the general prospectivity imperative include, inter alia, curative, restorative, validating, beneficial and procedural legislation, as well as legislation specifying statutes of limitation or providing for new remedies. ${ }^{57}$ Judicial practice benefits from academic systematisations and conceptualisations, but also verifies and corrects them. Lenience to some types of retroactivity provides no safe umbrella for every single instance of retroactive law-making, which nominally falls into one of the exceptions. Their application is challengeable. ${ }^{58}$ Predictability rules, even if not absolutely.

54 C. SAMPFORD. Op. cit., note 35 supra, p. 47.

55 Ümmühan Kaplan v. Turkey (no. 24240/07, 20 March 2012). After the application of the pilot judgment procedure a new domestic remedy has been established in Turkey, which was capable of offering a reasonable prospect of redress for complaints concerning the length of proceedings. The Court continued with the examination of applications of the same type which were already communicated to the Government; others were dismissed on the ground that the applicants had failed to exhaust the domestic remedies.

56 Savickas and Others v. Lithuania ((dec.), nos. 66365/09, 12845/10, 28367/11, 29809/10, 29813/10 and 30623/10, 15 October 2013).

57 C. SAMPFORD. Op. cit, note 35 supra, pp. 103-164. To justify them, a range of arguments is used: the necessary evil argument; the better rule argument; the better institution argument; the efficiency argument; the fairness argument. Ibid., pp. 229-256.

58 Cf., e.g., cases where so-called interpretive regulation has been enacted supposedly clarifying the provisions of the previous regulation, yet, in fact, changing that regulation essentially and thereby interfering into the cases already pending before courts. Stefanetti and Others $v$. Italy (nos. 21838/10, 21849/10, 21852/10, 21860/10, 21869/10 and 21870/10, 14 April 2014); Azienda Agricola Silverfunghi S.a.s. v. Italy (nos. 48357/07, 56277/07, 52687/07 and 52701/07, 24 June 2014). 


\section{QUALITY OF THE LAW AS A PREREQUISITE FOR THE RULE OF LAW}

The Statute of the Council of Europe refers to the rule of law twice: in the Preamble, where the signatory Governments affirm their devotion to the rule of law, and in Article 3, which provides that "every member ... must accept the principles of the rule of law". In the Convention, the reference is made once: in the Preamble. ${ }^{59}$ The Court has expressed its conviction that the signatory Governments had the "profound belief in the rule of law". ${ }^{0}$ The drafters of the Convention saw the rule of law as an inherent part of the common heritage of the democratic States that formed the Council of Europe, tacitly leaving it to the Strasbourg Court to develop the concept further. ${ }^{61}$ In the Court's case-law the rule of law has acquired the weight of a general principle, which must be taken into consideration when examining all complaints within the ambit of the Court's jurisdiction, in the light of which provisions of the Convention are interpreted and applied, ${ }^{62}$ although the Court was not intended to be a court of the rule of law (consequently, not an equivalent of a constitutional court as a negative legislator), but one of human rights. Such development, however, is natural, because in the Western legal tradition the rule of law and human rights are intrinsically interwoven.

As said above, the idea of the rule of law is not monopolised by any single legal order and is collectively interpreted by many courts. As a general principle, whose central element is legality, it covers all spheres of life, capable of being regulated by law. There may be no legal regulation, exempt from control in respect of its compliance with this standard. In this regard, the Convention's parallel with a constitution is appropriate. A constitution is integral; it has no gaps in that (Kelsenian) sense that, for the purposes of constitutional review, there can be no areas where legality rests and it cannot be tested whether certain act or decision is in compliance with the constitution. The opposite would imply a constitutionally-approved domain of legitimate arbitrariness. The Convention, however, has gaps. It focuses on one, even if wide, segment of social reality: human rights. Other segments are outside its ambit. This results in dismissal, by the Court, of complaints concerning alleged violations of rights belonging to these other areas as incompatible ratione materiae with the provisions of the Convention. The sphere of application of the rule of law as a constitutional principle is wider than that of its application as of a conventional principle. National rule of law doctrines tend to be holistic; the Court's doctrine particularistic. But the Convention is a living instrument, whose interpretation by the Court evolves "towards the moral truth of the [Convention] rights". ${ }^{63}$ As time goes by, its case-law may occupy new areas in two ways: a right not

59 The term has not been translated into all languages of member States literally. Its equivalent in French is prééminence du droit, literally "primacy of law". This term has been officially translated in my native Lithuanian as "teisès viršenybë", i.e. "supremacy of law", but in the domestic legal discourse two other terms are used perhaps even more often: "teisine valstybe" (literally "legal state") and "teisés viešpatavimas" (literally "the reign of law").

60 Golder v. the United Kingdom (no. 441/70, § 34, 21 February 1975).

61 P. Lemmens. "The Contribution of the European Court of Human Rights to the Rule of Law". In: G. De Baere, J. Wouters (eds). The Contribution of International and Supranational Courts to the Rule of Law. Cheltenham/Northampton MA, 2015, pp. 231-232.

62 Ibid., p. 241.

63 G. Letsas. A Theory of the Interpretation of the European Convention on Human Rights. Oxford/New York: Oxford University Press, 2007, p. 79. 
guaranteed by the Convention may be protected and defended by invoking other Articles, which cover its (or related right's) implementation; ${ }^{64}$ or the Article may be interpreted expansively, so that the right enshrined in it widens in content. ${ }^{65}$ But even such expansion will always have its limits.

It is not easy to formulate a concise academic definition of the rule of law, other than indication of its opposition to arbitrariness, but it would be even more difficult to define it in a court's judgment. The essence of the Court's rule of law doctrine is contained in this apt sentence: "The Court cannot accept that a decision-making power by the executive to detain the applicant on the basis of perceived fears of future non-violent criminal conduct unrelated to his original murder conviction accords with the spirit of the Convention, with its emphasis on the rule of law and protection from arbitrariness." ${ }^{66}$ The rule of law thus is conceived as the opposite of arbitrariness and part of the spirit of the Convention.

Like constitutional justice has contributed to Rechtsstaat's approximation to the rule of law by crystallising the criteria for telling the contrast between the rule of law and arbitrary power, so has the Strasbourg Court's case-law. None of the Articles of the Convention uses the word "arbitrary", but all the articles that enshrine respective rights have an in-built

64 For instance, the right to health is not as such among those guaranteed under the Convention (Dossi and Others v. Italy ((dec.), no. 26053/07, 12 October 2010). Member States have, parallel to their positive obligations under Article 2, a positive obligation under its Article 8, firstly, to have in place regulations compelling both public and private hospitals to adopt appropriate measures for the protection of their patients' physical integrity, and, secondly, to provide victims of medical negligence with access to proceedings in which they could, where appropriate, obtain compensation for damage (Trocellier v. France ((dec.), no. 75725/01, 5 October 2006; Codarcea v. Romania, no. 31675/04, § 103, 2 June 2009; Jurica v. Croatia, no. 30376/13, § 84, 2 May 2017). Health and health care-related cases (including alleged abuses in the health care institutions), therefore, are not rare, but are examined under other Articles (2, 6, 8 or even 9 or 14) (see, among many authorities, Korošec v. Slovenia (no. 77212/12, 8 October 2015), Dubská and Krejzová v. the Czech Republic ([GC], nos. 28859/11 and 28473/12, 15 November 2016; Lopes de Sousa Fernandes v. Portugal ([GC], no. 56080/13, 19 December 2017; Carvalho Pinto de Sousa Morais v. Portugal (no. 17484/15, 25 July 2017; Mockutè v. Lithuania (no. 66490/09, 27 February 2018).

65 To give one example, the Court has interpreted the notion of "private life" within the meaning of Article 8 as encompassing the right for an individual to form and develop relationships with other human beings, including relationships of a professional or business nature; that Article thus protects the right to personal development and the right to establish and develop relationships with other human beings and the outside world and does not exclude in principle activities of professional or business nature, because it is in the course of their working lives that the majority of people have a significant opportunity to develop relationships with the outside world (Oleksandr Volkov v. Ukraine, no. 21722/11, § 165, 9 January 2012). In Erményi v. Hungary (no. 22254/14, 22 November 2016) the Court went further. The applicant, who was dismissed from the post of the Vice-President of the Supreme Court, complained under Articles 6,13 and 14, but the Court, being "master of the characterisation to be given in law to the facts of the case" and relying on the jura novit curia principle, requalified his complaint as falling under Article 8. Domestic courts reinstated the applicant in his judicial service, but not to his previous administrative position in court system. On this account, the Court found a violation of Article 8. It transpires from the judgment that the applicant's "relationships with the outside world", his social life or even his professional relations were dependent on that post, which was but an additional function to his judicial service and status as a judge of the Supreme Court. The notion of "private life" thus (regrettably) tended to embrace virtually any act by the authorities vis-à-vis an individual, as a participant in the labour market or as a holder of a profession or any other official function. Update-note after the submission of the article: Quite soon the Court, having provided a survey of its private life case-law to date and having recapitulated its main principles, formulated a broad doctrine, backed away from an excessively broad interpretation of the concept of "private life" as employed in Erményi (cited above), and found a complaint under Article 8, in many respects similar to that in Erményi, to be incompatible ratione materiae with the Convention and thus inadmissible, although without formally denouncing Erményi (Denisov v. Ukraine ([GC], no. 76639/11, 25 September 2018).

66 Stafford v. The United Kingdom ([GC], no. 46595/99, § 82, 28 May 2002). 
anti-arbitrariness germ. For instance, Article 2 is directed against arbitrary deprivation of life; the purport of Article 5 is protection against arbitrary deprivation of liberty; that of Article 6 is guaranteeing the right to a fair, i.e. non-arbitrary, trial; Article 18 prohibits abusive restriction of individuals' rights, i.e. their restriction by arbitrary exercise of power by authorities. The Court's judgments, whatever their merits or disadvantages, thus are of anti-arbitrary spirit (and unfortunate exceptions do not alter the main direction). Some types of cases are especially telling in this regard, such as those pertaining to: excessive length of proceedings; ${ }^{67}$ torture $;{ }^{68}$ police violence ${ }^{69} ;$ non-implementation of courts' final judgments ${ }^{70}$; secret detention sites ${ }^{71}$; or persecution of political opponents ${ }^{72}$.

Rule of law-related fragments of the Court's doctrine are dispersed over its different judgments. The Court has never attempted to put them together into a lengthier whole. ${ }^{73}$ It uses the rule of law as an interpretational tool to give a meaning to a respective provision of the Convention, always in combination with one or several Articles of the Convention, which it considers to constitute a specific application of that principle. ${ }^{74}$ Given the nature of the Strasbourg Court as an international court, the principle of subsidiarity and the margin of appreciation reserved for member States, a universalised or too detailed definition of the ideal of the rule of law could be even counterproductive. ${ }^{75}$ The Court has developed an authentic concept of the rule of law, which tallies in some respects with that formulated by the national courts, and yet it is far from embracing the whole comparative jurisprudential variety of this concept.

It took time for the Court to consolidate the rule of law as a general conventional principle. The rule of law initially came to be mentioned in judges' separate opinions, rather than in the body of the Court's judgments. ${ }^{76}$ Only in 1975, in Golder v. the United Kingdom, the Court noted that the Preamble of the Convention "points to [the rule of law] as being one of the features of the common spiritual heritage", dismissed the interpretation of the rule of law as of "a merely 'more or less rhetorical reference', devoid of

67 Sürmeli v. Germany ([GC], no. 75529/01, 8 June 2006).

68 Gäfgen v. Germany ([GC], no. 22978/05, 1 June 2010).

69 Khamidov v. Russia (no. 72118/01, 15 November 2007).

70 Yuriy Nikolayevich Ivanov v. Ukraine (no. 40450/04, 15 October 2009).

71 Al Nashiri v. Poland (no. 28761/11, 24 July 2014); Husayn (Abu Zubaydab) v. Poland (no. 7511/13, 24 July 2014); Al Nashiri v. Romania (no. 33234/12, 31 July 2018); Abu Zubaydab v. Lithuania (no. 46454/11, 31 May 2014).

72 Gusinskiy v. Russia (no. 70276/01, 19 May 2004); Tymoshenko v. Ukraine (no. 49872/11, 30 April 2013); Ilgar Mammadov v. Azerbaijan (no. 15172/13, 22 May 2014); Rasul Jafarov v. Azerbaijan (no. 69981/14, 17 March 2016); Merabishvili v. Georgia ([GC], no. 72528/13, 28 November 2017).

73 Constitutional courts sometimes produce lengthier texts on this issue, as they perform norm control and interpret the respective constitution as an integral act. For example, the Lithuanian Constitutional Court has done this in its ruling of 13 December 2004 (available in English at http://www.lrkt.lt/en/court-acts/search/170/ta1279/ content (accessed on 29 June 2018)), where it systematised many fragments of its rule of law doctrine, accumulated throughout years. Still, later rulings added new elements to this doctrine.

74 P. Lemmens. Op. cit., note 61 supra, pp. 240-241. For some constitutional courts (including the Lithuanian Constitutional Court), as courts of norms, it is not wholly uncommon to rule that the challenged legislation is in conflict with the constitutional principle of the rule of law (or another constitutional principle, such as separation of powers), conceived as an autonomous constitutional provision, although reflected in and permeating various articles of the respective constitution.

75 Cf. M. Krygier. Op. cit., note 37 supra, pp. 262-263.

76 See, e.g., Individual dissenting opinion of Judge [Mehmed] Zekia, Wemhoff v. Germany (no. 2122/64, 27 June 1968). 
relevance for those interpreting the Convention", and used it as a tool for interpretation of Article $6 \S 1$ (and, by extension, Article 8): "in civil matters one can scarcely conceive of the rule of law without there being a possibility of having access to the courts". ${ }^{77}$ This notion was soon referred to in another case in the context of Article $5 \S 1$; the Court rejected the respondent Government's argument that the provisional arrest of the applicant was justified under sub-paragraph b) of that Article insofar as the latter permits "lawful arrest or detention [intended to] secure the fulfilment of any obligation prescribed by law", and stated that these words "concern only cases where the law permits the detention of a person to compel him to fulfil a specific and concrete obligation which he has until then failed to satisfy", but their "wide interpretation would entail consequences incompatible with the notion of the rule of law from which the whole Convention draws its inspiration". ${ }^{78}$ In yet another case, where domestic legislation was challenged as permitting surveillance measures without obliging the authorities in every case to notify the persons concerned after the event, the Court stated that "[t]he rule of law implies, inter alia, that an interference by the executive authorities with an individual's rights should be subject to an effective control which should normally be assured by the judiciary, at least in the last resort, judicial control offering the best guarantees of independence, impartiality and a proper procedure". ${ }^{79}$ Not much later the "fundamental principle of the rule of law" was invoked for interpreting "authority and impartiality of the judiciary" within the context of Article 10. ${ }^{80}$ Throughout the 1980s and 1990s the Court casuistically was filling this principle with concrete content, pertaining to: presumption of innocence $;^{81}$ right to liberty $;^{82}$ right to respect for private and family life, ${ }^{83}$ freedom of expression related to the "belief concerning the nature of human life" and the "right to life of the unborn"; $; 4$ the right to appeal ${ }^{85}$ interference by the legislature with the administration of justice aimed at influencing the judicial determination of disputes already pending before courts ${ }^{86}$ etc.

In this step-by-step manner, the Court proceeded to gradually intensify and solidify its reliance on the rule of law as a general principle, adding this additional argument to the requirements (under various Articles of the Convention) often already formulated in

$77 \S 34$, note 60 supra. But see Separate opinion of Judge Sir Gerald Fitzmaurice: "The importance attributed to the factor of the 'rule of law' ... is much exaggerated. That element, weighty though it is, is mentioned only incidentally in the Preamble to the Convention. What chiefly actuated the contracting States was not concern for the rule of law but humanitarian considerations."

78 Engel and Others $v$. The Netherlands ([Plenary], nos. 5100/71, 5101/71, 5102/71, 5354/72 and 5370/72, § 69, 8 June 1976). That paragraph refers to Golder (note 60 supra), but it is not explicitly stated in Golder that the (whole) Convention draws inspiration from the notion of the rule of law.

79 Klass and Others v. Germany ([Plenary], no. 5029/71, §55, 6 September 1978). The Court found no violation of Articles 6, 8 and 13 of the Convention.

80 The Sunday Times v. the United Kingdom ([Plenary], no. 6538/74, § 55, 26 April 1979).

81 Salabiaku v. France (no. 10519/83, § 28, 7 October 1988).

82 Brogan and Others v. the United Kingdom ([Plenary], 11266/84, § 58, 29 November 1988); Brannigan and McBride v. the United Kingdom ([Plenary], no. 14553/89, 14554/89, § 48, 26 May 1993).

83 Huvig v. France (no. 11105/84, § 26, 24 April 1990); Kruslin v. France (no. 11801/85, §§ 27, 30, 32,36 and 24 April 1990); Herczegfalvy v. Austria (no. 10533/83, §§ 88 and 89, 24 September 1992).

84 Open Door and Dublin Well Woman v. Ireland ([Plenary], nos. 14234/88 and 14235/88, § 69, 29 October 1992).

85 Poitrimol v. France (no. 14032/88, § 38, 23 November 1993).

86 Stran Greek. Refineries and Stratis Andreadis v. Greece (no. 13427/87, §§ 46 and 49, 9 December 1994). 
its case-law. It is not excluded that the Court was inspired by the judgments of domestic constitutional courts (most notably of the German and Swiss ones) which it cited, where provisions of domestic legislation and (in cases of individual complaints) their application were examined as to their compliance with the imperative of the rule of law, as (explicitly or implicitly) enshrined in a respective constitution. ${ }^{87}$

The general doctrinal provision as to the scope of potential of use of the notion of the rule of law $^{88}$ was introduced in 1996, in Amuur $v$. France: this concept was referred to as one "inherent in all the Articles of the Convention". ${ }^{99}$ That case concerned the deprivation of liberty, which, under Article $5 \S 1$, must be effected "in accordance with a procedure prescribed by law". While substantiating that the principle of the rule of law is inherent in all the Articles of the Convention, the Court cited also the similar clauses of Articles $8 \S 2,9 \S 2,10 \S 2$, and $11 \S 2$, which all require that the "quality of the law $\ldots$ is compatible with the rule of law". ${ }^{90}$ That Amuur formula was referred to in a number of Chamber judgments, and in 1999 it was adopted by the Grand Chamber; ${ }^{91}$ since then, it has become routine.

Under Article 1 of the Convention, the High Contracting Parties shall secure to everyone within their jurisdiction the rights and freedoms "defined in Section I of [the] Convention". The States thus must take all measures necessary to protect these rights, and if they are infringed, to rectify the matter. In the Court's interpretation of the Convention, the States have a positive obligation to set up a normative framework for ensuring Convention rights. It falls on domestic law-making bodies. For the Convention purposes, domestic rules (even constitutional) governing the law-making competences of these bodies are irrelevant (unlike for constitutional courts that may disqualify as unconstitutional even such legislation which would ensure human rights, if it has been adopted by an inappropriate institution or in an inappropriate procedure). The said obligation pertains to all Convention rights.

For an interference into a right to not constitute a violation of the Convention, the first condition is that it must be "provided by law" or "in accordance with the law". These provisions require that that impugned measure has "some basis" in domestic law, ${ }^{92}$ which "must be adequately accessible and be formulated with sufficient precision

87 Zimmermann and Steiner v. Switzerland ([GC], no. 8767/79, 13 July 1983); Glasenapp v. Germany ([Plenary], no. 9228/80, 28 August 1986); Kosiek v. Germany ([Plenary], no. 9704/82, 28 August 1986); Lüdi v. Switzerland (no. 12433/86, 15 June 1992); Vogt v. Germany ([GC], no. 1785/91, 26 September 1995).

88 Other than the statement in Engel and Others (note 78 supra) that the whole Convention draws its inspiration from the notion of the rule of law.

89 Amuur v. France (no. 19976/92, § 50, 25 June 1996).

$90 \mathrm{Ibid}$. The notion of the quality of the law, however, was already used in some earlier judgments. Huvig $v$. France ( $\$ \$ 26$ and 29, note 83 supra); Kruslin v. France ( $\$ 27$ and 30, note 83 supra); Herczegfalvy v. Austria (no. $10533 / 83, \S 88$, note 83 supra).

91 Iatridis v. Greece ([GC], no. 31107/96, § 58, 25 March 1999); Stafford v. the United Kingdom (§ 63, note 66 supra). A parallel: the Lithuanian Constitutional Court, while elaborating that all constitutional provisions are interrelated and form an integral, harmonious system, held that the constitutional principle of a state under the rule of law is "a universal one upon which the whole Lithuanian legal system as well as the Constitution of the Republic of Lithuania itself are based" and that the content of the principle of a state under the rule of law "can be detected in various provisions of the Constitution" (ruling of 23 February 2000; available in English at http://www.lrkt.lt/en/ court-acts/search/170/ta1156/content (accessed on 29 June 2018)).

92 Kopp v. Switzerland (no. 23224/94, § 55, 25 March 1998); Amann v. Switzerland ([GC], no. 27798/95, § 50, 16 February 2000); Rotaru v. Romania ([GC], no. 28341/95, § 52, 4 May 2000); Sanoma Uitgevers B.V. v. The 
to enable the citizen to regulate his conduct, he or she being able —if need be with appropriate advice - to foresee, to a degree that is reasonable in the circumstances, the consequences which a given action may entail". ${ }^{93}$ Such requirements as clarity or legal certainty are quality requirements, an extension and specification of the general concept of the rule of law and its aide as of an interpretative tool. If the rule of law is inherent in all the Articles of the Convention, so must be its quality elements. For instance, legal certainty is held to be "implicit in all the Articles of the Convention and [to] constitut[e] one of the fundamental aspects of the rule of law". ${ }^{94}$

In the Court's case-law, quality of the law initially was mentioned sporadically, often referring to its predictability, foreseeability, accessibility and clarity, rather than to its substance. In Malone v. the United Kingdom the Court stated that "the phrase in accordance with the law' does not merely refer back to domestic law but also relates to the quality of the law, requiring it to be compatible with the rule of law" ${ }^{95}$ In the $1980 \mathrm{~s}$ the expression "quality of the law" was used only episodically. ${ }^{96}$ In the 1990 s, its usage —or that of its twin "quality of the legal rules applied" - intensified; ${ }^{97}$ in Kopp $v$. Switzerland (and several other cases) the Court entitled a sub-section of the judgment "Quality of the law". ${ }^{98}$ In some cases it moved towards limited inclusion in the concept of the "quality of the law" of more substantive elements. Yet in Malone the Court (having referred to the European Commission on Human Rights) interpreted the expression "in accordance with the law" as implying also that "there must be a measure of legal protection in domestic law against arbitrary interferences by public authorities with the rights safeguarded by [Article $8 \S 1$ ].". ${ }^{99}$ This was echoed in Tolstoy Miloslavsky $v$. the United Kingdom: "A law which confers a discretion is not in itself inconsistent with this requirement, provided that the scope of the discretion and the manner of its exercise are indicated with sufficient clarity, having regard to the legitimate aim in question, to give the individual adequate protection against arbitrary interference." 100 In at least two cases the Court, using the notion of the "quality of the law" in the context of the right to privacy, reiterated that Article $8 \S 2$ requires "the law in question" to be "compatible with the rule of law" in that sense that, "because of the lack of public scrutiny [of secret measures of surveillance or interception of communications by public authorities] and the risk of misuse of power, the domestic law must provide some protection to the individual against arbitrary interference

Netherlands ([GC], no. 38224/03, § 81, 14 September 2010).

93 A, B and C v. Ireland (no. 25579/05, § 220, 16 December 2010).

94 Nejdet Şabin and Perihan Şabin v. Turkey ([GC], no. 13279/05, § 56, 20 October 2011).

95 Malone v. United Kingdom (no. 8691/79, § 67, 2 August 1984). The Court referred to two of its earlier judgments, wherein, however, the expression "quality of the law" has not been used.

96 James and Others $v$. the United Kingdom ([Plenary], 8793/79, § 67, 21 February 1986); Olsson v. Sweden ([Plenary], no. 10465/83, § 61, 24 March 1988); Chappell v. the United Kingdom (10461/83, § 57, 30 March 1989).

97 Huvig v. France ( $\$ 26$ and 29, note 83 supra); Margareta and Roger Andersson v. Sweden (no. 12963/97, § 75, 25 February 1992); Kruslin v. France ( $\$ 112$ and 30, note 83 supra); Herczegfalvy v. Austria ( 88 , note 83 supra); Halford v. the United Kingdom (no. 20605/92, § 49, 25 June 1997); Tolstoy Miloslavsky v. the United Kingdom (no. 18139/91, § 37, 13 July 1995); Kopp v. Switzerland ( $\$ 55$ and 66, note 92 supra); Lambert v. France (no. 23618/94, $\S 23,26-28,24$ August 1998); Amuur v. France (\$ 50, note 91 supra); Valenzuela Contreras v. Spain (no. 27671/95, $\S \S 46,53$ and 60, 30 July 1998); McLeod v. the United Kingdom (24755/94, § 41, 23 September 1998).

98 Kopp v. Switzerland $(\$ \S 62-75$, note 92 supra).

99 Malone v. United Kingdom ( $\$ 67$, note 95 supra).

100 Tolstoy Miloslavsky $v$, the United Kingdom (\$ 37, note 97 supra). 
with Article 8 rights", therefore it "must be sufficiently clear in its terms to give citizens an adequate indication as to the circumstances in and conditions on which public authorities are empowered to resort to any such secret measures". ${ }^{101}$ The foreseeability of law was underlined in some other cases, without directly mentioning the "quality of the law". ${ }^{102}$ The breakthrough came in 2000, when this expression was adopted by the Grand Chamber in Amann v. Switzerland $d^{103}$ and two other cases. ${ }^{104}$

The quality of the law signifies a standard of its excellence. It is a one-to-many concept. It refers to various formal aspects of the law, but also to all manner of elements of its content. The above-cited requirements for quality law bear primarily on its form and only indirectly on its contents. In terms of thick-thin spectre of concepts, they are closer to the thin side. Given that the quality of the law is an extension of the rule of law as an interpretative tool, used in combination with certain Articles of the Convention as specific applications of the rule of law, it is natural to expect that more substantive (thicker) elements of the rule of law are to be found in the doctrines pertaining to the interpretation of these Articles (similarly to their discovery, by constitutional courts, in various articles of even those constitutions which do not directly mention the rule of law or the law-governed state).

The Court's rule of law doctrine recently has been recapitulated in De Tommaso $v$. Italy. The law in question should be accessible to the persons concerned and foreseeable as to its effects; "a norm cannot be regarded as a 'law' unless it is formulated with sufficient precision to enable citizens to regulate their conduct; they must be able —if need be with appropriate advice - to foresee, to a degree that is reasonable in the circumstances, the consequences which a given action may entail". The unattainable (even if highly desirable) is not required: the consequences of the action must not be foreseeable with absolute certainty; the level of precision cannot provide for every eventuality; and the law must be able to keep pace with changing circumstances. It is conceded that many laws are inevitably couched in (to a greater or lesser extent) vague terms, whose interpretation and application are questions of practice. A foreseeable rule is such which affords a measure of protection against arbitrary interferences by the public authorities; if a law confers a discretion, it must indicate the scope of that discretion, but the detailed procedures and conditions to be observed do not necessarily have to be incorporated in rules of substantive law. ${ }^{105}$

Predictability of law and legal certainty as inherent elements of the rule of law and requirements for the quality of the law may have some peculiarities with regard to judgemade law. In a case against the United Kingdom, the Court pronounced that "the word 'law' covers not only statute but also common law". ${ }^{106}$ It has not been expounded unequivocally as to how much inclusion of "common law" in the predictability of law requirement extends also to case-law of the courts that do not belong to common law tradition. But it has

101 Halford v. the United Kingdom ( $\$ 49$, note 97 supra); Kopp v. Switzerland ( $\$ 64$, note 92 supra).

102 See, e.g.: Rekvényi v. Hungary (no. 25392/94, § 34, 20 May 1999); Hashman and Harrup v. the United Kingdom (no. 25594/94, § 31, 25 November 1999).

103 Amann v. Switzerland ( $\$ 50$ and 55-63 (sub-section), note 92 supra).

104 Rotaru v. Romania ( $\$ 52,55$ and 56, note 92 supra); Hasan and Chaush v. Bulgaria ([GC], no. 30985/96, $\S 84,26$ October 2000).

105 De Tommaso v. Italy ([GC], no. 43395/09, §§ 106-109, 23 February 2017).

106 Tolstoy Miloslavsky v. the United Kingdom ( $\$ 37$, note 97 supra). 
been recognised that: "however clearly drafted a legal provision may be, in any system of law, including criminal law, there is an inevitable element of judicial interpretation"; "[t]here will always be a need for elucidation of doubtful points and for adaptation to changing circumstances"; and that "the progressive development of the criminal law through judicial interpretation is a well-entrenched and necessary part of legal tradition" ${ }^{107}$ It also has been elucidated that: legal certainty "guarantees certain stability in legal situations and contributes to public confidence in the courts"; the "persistence of conflicting court decisions can create a state of legal uncertainty likely to reduce public confidence in the judicial system, whereas such confidence is clearly one of the essential components of a State based on the rule of law ..., especially when these conflicting decisions appear in similar cases heard in the same court which, in addition, is the court of last resort in the matter"; "the possibility of conflicting court decisions is an inherent trait of any judicial system that is based on a network of trial and appeal courts with authority over the area of their territorial jurisdiction"; "divergences may also arise within the same court"; "[t]hat, in itself, cannot be considered contrary to the Convention"; "[t]he requirements of legal certainty and the protection of the legitimate confidence of the public do not confer an acquired right to consistency of case-law"; and "[c]ase-law development is not, in itself, contrary to the proper administration of justice, since a failure to maintain a dynamic and evolutive approach would risk hindering reform or improvement". In line with this doctrine, the Court does not see its function in comparing different decisions of national courts, even if given in apparently similar proceedings, as "giving two disputes different treatment cannot be considered to give rise to conflicting case-law when this is justified by a difference in the factual situations at issue". In its assessment of the circumstances in which contradictory decisions by different domestic courts, ruling at final instance, entail a violation of the right to a fair hearing, enshrined in Article $6 \S 1$, the Court, in its own words, is guided by the following criteria: whether "profound and long-standing differences" exist in the case-law of the domestic courts; whether the domestic law provides for a mechanism for overcoming these inconsistencies; whether that mechanism has been applied and, if appropriate, to what effect. ${ }^{108}$ On such basis, the Court may find a either a violation, ${ }^{109}$ or no violation ${ }^{110}$ of Article $6 \S 1$.

The analytical divide between the formal and the substantive aspects of the quality of the law does not prevent them from being bridged. Where a law authorises a deprivation of liberty, its quality implies sufficient accessibility, precision and foreseeability in its application to avoid all risk of arbitrariness; ${ }^{111}$ "lawfulness" covers procedural as well as substantive rules; and in a democratic society subscribing to the rule of law no arbitrary detention can ever be regarded as lawful. ${ }^{112}$ But generally law must not be precise to every detail; the level of required precision depends to a considerable degree on the content of the law. ${ }^{113}$ When assessing the quality of the law, a balance is sought between

107 Vasiliauskas v. Lithuania ([GC], no. 35343, § 155, 20 October 2015).

108 Lupeni Greek Catholic Parish and Others v. Romania ([GC], no. 76943/11, § 116, 29 November 2016).

109 See, e.g., Beian v. Romania (no. 30658/05, 6 December 2007).

110 See, e.g., Borg v. Malta (no. 37537/13, 12 January 2016).

111 Del Río Prada v. Spain ([GC], no. 42750/09, 21 October 2013)

112 Winterwerp v. the Netherlands (no. 630173/73, § 39, 24 October 1979).

113 As well as on the field it is designed to cover and the number and status of those to whom it is addressed. Vogt v. Germany ( $\$ 48$, note 87 supra); Rekvényi v. Hungary ( $\$ 34$, note 102 supra); RTBF v. Belgium (no. 50084/06, $\S 104,29$ March 2011); De Tommaso v. Italy (§ 108, note 105 supra). 
its accessibility, clarity and foreseeability, and the need to avoid the "excessive rigidity of the law". ${ }^{114}$ Also, the first-time application of the new law does not, in itself, render that law unforeseeable, because "there must come a day when a ... legal norm is applied for the first time". ${ }^{115}$ The doctrine of the quality of the law having evolved that far, it is in fact immaterial whether a the notion of quality of the law is explicitly mentioned in a judgment: it is assessed anyway.

For example, a violation of Article 7 was found, where laws fixed different minimum penalties, and the public prosecutor had a discretion to decide in which court to try an accused and which particular punishment bracket applied to him. ${ }^{116}$ Where the applicant complained about the lack of any remedy before a national authority that could rule on his application for destruction of the file containing information about him and amendment of the inaccurate information, a violation of Article 13 was found on account that domestic law had not made it possible to challenge the holding, by agents of the State, of information on a person's private life or the truth of such information. ${ }^{117}$ In yet another case the applicant complained that during the first ten years of his postconviction detention for life his ability to receive prison visits from his wife and other family members had been severely curtailed; a violation of Article 8 was found on account that a fair balance has not been struck between the applicant's right to the protection of private and family life and a legitimate aim of isolating such people from society. ${ }^{118}$ But the Court was satisfied with the Constitutional Court's finding that the sanctioning of the court witness for not taking off his skullcap in the courtroom had a basis in the domestic law, which was far from being express on this issue. ${ }^{119}$

There may be a new trend showing up. In Roman Zakharov v. Russia, the Court found a violation of Article 8 on the account that domestic legal provisions governing interceptions of communications lacked clarity; did not provide for adequate and effective guarantees against arbitrariness and the risk of abuse; and did not ensure that secret surveillance measures are ordered only when "necessary in a democratic society". The applicant was unable to allege that he has been subject to a concrete measure of surveillance. Still he claimed to be a victim of a violation "by the mere existence of legislation which allowed a system of secret interception of communications, without having to demonstrate that such secret measures had been in fact applied to him", because the "existence of such legislation entailed a threat of surveillance for all users of the telecommunications services and ... amounted in itself to an interference with the exercise of his rights under Article 8". The Court held that the "mere existence of the contested legislation amounts in itself to an interference". ${ }^{120}$ This non-formalism goes far, especially in view of abundant instances of restrictive approach to applicants' victim status, as well

114 Rekvényi v. Hungary ( $\$ 34$, note 102 supra). Balancing, however, is a challenging —if not essentially contested-concept, owing to the contrariety of its paradigms. The aspect is not dealt with here.

115 Kudrevičius v. Lithuania ([GC], no. 37553/05, 15 October 2015).

116 Camilleri v. Malta (no. 42931/10, 22 January 2013).

117 Rotaru v. Romania (note 92 supra).

118 Khoroshenko v. Russia ([GC], no. 41418/04, 30 July 2015).

119 Hamidović v. Bosnia and Herzegovina (no. 57792/15, 5 December 2017). The violation of Article 9 nevertheless has been found on account of the disproportionality of the sanction to the legitimate aims pursued.

120 Roman Zakharov v. Russia ([GC], no. 47143/06, 4 December 2015). 
as the oft-repeated doctrine that the Court's task is not normally to review the relevant law and practice in abstracto, but to determine whether the manner in which they were applied to or affected the applicant gave rise to a violation of the Convention. Or rather- it could go very far, if the application of this approach (which is by all standards applicant- and human-rights-friendly) is not confined to the circumstances of that particular case or those of other similar cases, where the very existence of impugned legislation poses a permanent threat to an individual's right under the Convention and thus amounts to a direct infringement of the respective right. This "directness" perhaps is easier to substantiate in right to privacy cases, but such substantiation would not be as easy with regard to other rights enshrined in the Convention. The temptation for expansion of this approach, however, may appear to be very strong and indeed irresistible (especially in cases of blatant disregard of rights). Even if one agrees in principle (as I do) that Russian domestic normative framework disregarded the right to privacy of population at large (thus also of the applicant), the approach taken has resulted in the Court acting as a court of norms, i.e. a constitutional court.

Another indication of this trend (or departure from the more formalistic mainstream) is the life imprisonment case-law. In Kafkaris v. Cyprus, the Court assessed the quality of the impugned law and, found a violation of Article 7 on account that as a consequence of the change in the law, the applicant, a life prisoner, no longer could to have his sentence remitted, contrary to the requirement that the changes in legislation and in the conditions of release cannot be construed as imposing a heavier "penalty" than that imposed by the trial court. But the Court did not find a violation of Article 3, holding that life sentences in Cyprus were "both de jure and de facto reducible" by presidential pardon. ${ }^{121}$ In only five years, in Vinter and Others $v$. the United Kingdom, the Court's approach to the lifers' "right to hope" made a U-turn. ${ }^{122}$ Violations of Article 3 are found in cases where the Court holds that life sentences are irreducible, and they are considered to be irreducible even if there are such mechanisms available as presidential pardon (which was justified as sufficient in Kafkaris), amnesty, or release on compassionate grounds. Legislative instruments are required, allowing for periodic review (upon request) of life sentences and proper consideration of the progress towards rehabilitation made by a lifer. What is more, in the absence of effective review, life sentence's incompatibility with Article 3 arises already at the moment of imposition of that sentence. ${ }^{123}$ Not calling into question the findings in Vinter and Others (they merit praise for promoting a humanist approach), this turnaround raises queries. How can a State be liable even in such cases, where the normative framework has not been

121 Kafkaris v. Cyprus ([GC], no. 21906/04, 12 February 2008).

122 Vinter and Others $v$. the United Kingdom ([GC], nos. 66069/09 130/10 3896/10, 7 July 2013).

123 Vinter and Others $v$. the United Kingdom (note 122 supra); Öcalan v. Turkey (no. 2) (no. 24069/03, 197/04, 6201/06 and 10464/07, 18 March 2014); Trabelsi v. Belgium (no. 140/10, 4 September 2014); Lászlo Magyar v. Hungary (no. 73593/10, 14 May 2014); T.P. and A.T. v. Hungary (37871/14, 73986/14, 4 October 2016); Murray v. The Netherlands ([GC], no. 10511/10, 26 April 2016); Harakchiev and Tolumov v. Bulgaria (nos. 15018/11 and 61199/12, 8 July 2014); Matiošaitis and Others v. Lithuania (nos. 22662/13, 51059/13, 58823/13, 59692/13, 59700/13, 60115/13, 69425/13 and 72824/13, 23 May 2017). Cf. Čačko v. Slovakia (no. 49905/08, 22 July 2014); Bodein v. France (nr. 40014/10, 13 November 2014); Hutchinson v. the United Kingdom ([GC], no. 57592/08, 17 January 2017); Harkins v. the United Kingdom ([GC], (dec.), no. 71537/14, 17 January 2017). 
worsened (or even has been improved) since the last case against the same State, where no violation was found? ${ }^{124}$ If a person was sentenced to life imprisonment in the preVinter area, does that mean that the State has not complied with its obligation to set up a requisite normative framework already at the time of imposition of the sentence, although the existing framework met the criteria set forth in the Court's case law? ${ }^{125}$ How can the fact of absence of periodic review of life sentences alone render a life prisoner victim of violation of Article 3, if other mechanisms present in domestic legal framework offer some prospect (not really unreasonable) of early release, but a lifer deliberately makes no progress towards rehabilitation? And so on. These cases have moved the Court to the direction of constitutional courts, for whom examination of legislative omissions is part of their routine job. ${ }^{126}$

The dark side of the quality-of-the-law-reasoning is that it can be a tool for justification of impugned practices, if the Court holds that the sufficient quality of the legislation applied justifies an interference into a Convention right. In Garibv. the Netherlands, the interference into the applicant's freedom of movement was justified on that ground that the impugned legislation implemented the legitimate general measures (public policy). ${ }^{127}$ It may be argued that such approach is yet another indication of the Court's progressing self-approximation to constitutional courts. The extreme manifestation of such reasoning is highlighting the lack of the quality of the law in the judgment's operative part. ${ }^{128}$ On the other hand, in many cases a violation of a Convention provision was found owing to the unsatisfactory quality of the law (e.g., excessive rigidity), but the Court, having pointed to deficiencies, restrained itself from indicating them in the judgment's operative part: formally, violations were found on the account of the deficient manner of law-application, rather than deficiency of the law. ${ }^{129}$

Procedurally, the assessment of the quality of the law is a precondition for the assessment of law-application. This does not mean that, after it has been established that the impugned interference was based on the law, the quality of the law must be

124 T.P. and A.T. v. Hungary (note 123 supra). Cf. Törköly v. Hungary ((dec.), no. 4413/06, 5 April 2011). As one analyst put it (albeit in a different context), "ECtHR is allowed to 'play' the 'living instrument' as a soloist". C. DJeffal. "Dynamic and Evolutive Interpretation of the ECHR by Domestic Courts? An Inquiry into the Judicial Architecture of Europe”. In: H. P. Aust, G. Nolte (eds). The interpretation of International Law by Domestic Courts: Uniformity, Diversity, Convergence. Oxford: Oxford university Press, 2016, p. 177.

125 Matiošaitis and Others v. Lithuania (note 123 supra).

126 The Conference of European Constitutional Courts chose for its XIVth Congress (2008) the theme of legislative omission. The General report and national reports on respective practice are available in: E. JARAŠIŪNAS (ed.). Les problèmes de l'omission législative dans la jurisprudence constitutionnelle: Rapports. Problems of Legislative Omission in Constitutional Jurisprudence: Reports. Vilnius: Constitutional Court of the Republic of Lithuania, 2009.

127 Garib v. The Netherlands ([GC], no. 43494/09, 6 November 2017). On the echoing of this methodology that of Animal Defenders International v. the United Kingdom ([GC], no. 48876/08, 22 April 2013) see V. DAVID. "Strasbourg Fails to Protect the Rights of People Living in or at Risk of Poverty: The Disappointing Grand Chamber Judgment in Garib v. The Netherlands". https://strasbourgobservers.com/2017/11/16/strasbourg-fails-to-protect-the-rights-of-people-living-in-or-at-risk-of-poverty-the-disappointing-grand-chamber-judgment-in-garib-vthe-netherlands/\#more-4046 (accessed on 29 June 2018).

128 See, e.g., Kafkaris v. Cyprus (note 121 supra).

129 See, e.g.: Biao v. Denmark ([GC], no. 38590/10, 24 May 2016); Biržietis v. Lithuania (no. 49304, 14 June 2016); Urb̌̌iene and Urbšys v. Lithuania (no. 16580/09, 8 November 2016). This has been so even where violations found stemmed from constitutional provisions. Sejdić and Finci v. Bosnia and Herzegovina ([GC], nos. 27796/06 and 34836/06, 22 December 2009); Urechean and Pavlicenco v. Moldova (nos. 27756/05 and 41219/07, 2 December 2014). 
scrutinised in each and every case. First of all, the applicants may not (and often do not) raise this issue at all. Also, many cases are routine, and it is not so that a big part of laws applied are unforeseeable, inaccessible or unclear. Lawfulness of interference often is postulated without much explicit reasoning. If the law-application lacked legal basis, this fact alone determines the finding of a violation of the respective provision. Where it has been shown that an interference was not in accordance with the law, it is not necessary to investigate whether it also pursued a legitimate aim or was necessary in a democratic society. ${ }^{130}$

But the Court sometimes skips the examination of the lawfulness of interference (thus also the examination of the quality of the law), when it finds that the interference complained of has not pursued a legitimate aim and/or was not necessary in a democratic society or not proportional to the legitimate aim pursued. Holding that the "issue with the quality of law is secondary to the question of the necessity of the impugned measure" 131 may result from escapist stance in a sensitive matter or from pragmatic considerations as to the best use of the Court's resources, when scrutinising the quality of the law would be exceptionally time- and effort-consuming. But it also may result from (rightly or wrongly) perceived difficulties which the Court could encounter, where the issue under consideration is really borderline, so leaving the question of the quality of the law open would do less harm. National courts also employ various scope-of-examination-limiting techniques. In an ideal world, a court of the rule of law would not skip such questions. But the Strasbourg Court is not part of (non-existent) ideal world, and it was not intended to be a court of the rule of law. It just turned out so.

\section{BY WAY OF CONCLUSION}

This article is an agenda for reflection, so in fact no categorical or final conclusions can be presented. The quality of the law doctrine is an unfinished project. From the historical perspective, it is still nascent. The rule of law doctrine is also evolving and will never be completed, because it is part of the legal tradition, where law, including its highest standards, constantly reinterprets itself and draws its potential for growth from self-reinterpretation. Being (still) pluralist, it has not one way of approaching issues. The Strasbourg Court's approach to the rule of law and the quality of the law is one of them. Not the only one. Like any other court, the Strasbourg Court has had its ups and downs, its hours of glory and setbacks (korematsus too). The rule of law is what courts say about it, not some one court. Otherwise it would not be a shared idea. There is a lot of jurisprudential and other interchange between the Strasbourg Court and the judiciary of

130 Khan v. the United Kingdom (no. 35394/97, § 28, 12 May 2000); Dobrev v. Bulgaria (no. 55389, § 165, 10 August 2006); Giorgi Nikolaishvili v. Georgia (no. 37048/04, § 129, 13 January 2009); Church of Scientology of St Petersburg and Others $v$. Russia (no. 47191/06, $\S 47,2$ October 2014). As it is known, the typical test of examination of human rights cases (not only in the Strasbourg Court) consists of four steps, when it has to be established: (i) whether there had been an interference with a respective right; (ii) whether the interference was based on foreseeable; accessible and sufficiently clear law; (iii) whether it pursued a legitimate aim; and (iv) whether it was necessary in a democratic society and proportional.

131 Bayev and Others v. Russia (nos. 67667/09, 44092/12 and 56717/12, §§ 63-64, 20 June 2017); Sekmadienis Ltd. v. Lithuania (no. 69317/14, § 68, 30 January 2018). 
member States (so-called judicial dialogue), which facilitates coordination of their insights. Divergence, too, is there. But divergence is also part of a sharing process.

The quality of the law doctrine as an interpretative tool is a remarkable invention and at the same time the result of consequential development of the rule of law as a practicable concept. It is not uncontroversial and has not been always applied consistently. It leaves many questions open - and not only technical or procedural, but even fundamental ones. But it is a tool for searching for answers, in the same vein as the concept of the rule of law at large, which is also not a repository of answers "made in Strasbourg". The quality of the law doctrine can help to determine, whether the law under examination satisfies quality standards, but it cannot tell which of the options, from which national legislators have to choose, is of the best quality. This pertains to all spheres regulated by law.

To take just one example, let us look at the rule of law requirement of fair trial (making no references to specific respondent countries or the Court's cases). Some states have jury trial, others do not. Among those who have it, patterns of jury composition and selection, their relationship with the professional judge in the case and modes of giving a verdict vary. A question may be asked as to how to ensure that the jurors, who are laymen, are best prepared for their function and best perform it. Should they be instructed? If yes, then in what detail? Should they present reasons of the verdict? If yes, wherefrom do they know how to do this best? In some cultures it is believed that the instructions from the judge must be as thorough as possible. This seems to be in line with the Court's case-law, where it is underlined that the person convicted by a jury must be able to understand the verdict. Yet in other cultures it is believed that the more detailed instruction to the jurors, the lesser their independence. This also seems to be in line with the Court's case-law, with its emphasis of independence of courts. And what about countries which do not have jury? Their systems, too, seem alright for the Court's case-law, because they are (rightly) held less prone to external influences, such as trial by media. Within such systems there is an inner differentiation: some states have only professional judges, others have professional judges in combination with lay judges. The latter also must be instructed as to how to perform and be able to explain their decisions. So, which system would be, so to say, of highest quality and most conducive to the rule of law?

Neither the doctrine of the quality of the law, nor the Strasbourg doctrine of the rule of law can answer such questions. Their counterparts at the national level are able of more, as they can propose what would be best for a specific country, basing their considerations on a specific historical, cultural, political and legal heritage and their constitutional identity. But their insights and proposals not necessarily can be transplanted to foreign soil without such negative side effects which would surpass their merits. Strasbourg doctrines, as interpretative tools, also can provide some general guidance - but only up to the limit where the domain of national constitutional identity begins.

Constitutional identity is yet another concept that provokes more questions than provides answers. The very notion has several meanings. ${ }^{132}$ It can be interpreted narrowly, as relating only to constitutions, or broadly, where it includes historical and cultural experience, underlying the respective country's constitution. In general, the

132 See, e.g., J. L. Marti. "Two Different Ideas of Constitutional Identity: Identity of the Constitution v. Identity of the people". In: A. Saiz Arnaiz, C. Alcoberro Llivina (eds). National Constitutional identity and European Integration. Cambridge/Antwerp/Portland: Intersentia, 2013. 
Strasbourg Court's approach to member States' constitutional identities is respectful, although there is always a risk that sensitive constitutional provisions will be treated just like any law. This risk, alas, sometimes materialises. There have been also opposite eccentricities, when the Court bowed - to the detriment of individuals' rights - to what looked like national tradition, however dubious. To give just one example, in 1986 the Court paid obeisance to the Irish constitutional tradition of prohibition of divorce. It held that the absence of provision for divorce under Irish law and the resultant inability of the applicants (one of whom was formally in marriage with another person) to marry each other do not give rise to a violation of Articles 8 and 12 of the Convention. ${ }^{133}$ If one looks for an example of korematsu in the Strasbourg Court's case-law, this is one. Since then, divorces have been legalised all over Europe and the world; it thus can be claimed that there is a solid worldwide consensus on this issue. Still, in 2017, in a case against Poland, the Court again held that the provisions of the Convention cannot be interpreted as guaranteeing a possibility, under domestic law, of obtaining divorce. ${ }^{134}$ The Court fell hostage to its ancient (mildly put) questionable doctrine. In five years it resolutely moved from Kafkaris ${ }^{135}$ to Vinter and Others, ${ }^{136}$ so why could not it liberate itself from Johnston? ${ }^{137}$ After all, like the quality of the law doctrine is a tool, the Convention is also but a tool for achieving justice and enabling people to pursue happiness. Or it should be.

Lastly, and despite certain inconsistencies (of which no one is insured, even the most professional of courts), the standards of the rule of law have not been only crystallised by means of the Court's adjudication - they have been strengthened. In this respect, the European human rights journey overall has been a success story. But can these standards weaken, or be lowered? Such possibility cannot be excluded, especially given some member States' (whose number seems to increase) resistance to execution of the Court's judgments - at times deliberate and demonstrative. Whether this anti-systemic stance constitutes part of the alleged crisis of the Western legal tradition, or part of the rising new upheaval, which may once more result in this tradition becoming even stronger, is yet to be assessed in not so near future. In the meantime, and especially as no one knows what the Western world would be (if at all) after the rule of law, there is no alternative to making the best use of all the imperfect tools that its legal tradition has generated —including the interpretative ones.

Título: Sobre el Estado de Derecho y la calidad de la ley: reflexiones del juez constitucional que deviene internacional.

ABSTRACT: Western legal tradition gave the birth to the concept of the rule of law. Legal theory and constitutional justice significantly contributed to the crystallisation of its standards and to moving into the direction of the common concept of the rule of law. The European Court of Human Rights uses this concept as an interpretative tool, the extension of which is the quality of the law doctrine, which encompasses concrete requirements for the law under examination in this

133 Johnston and Others $v$. Ireland ([Plenary], no. 9697/82, 18 December 1986).

134 Babiarz v. Poland (no. 1955/10, 10 January 2017).

135 Kafkaris v. Cyprus (note 122 supra).

136 Vinter and Others $v$. the United Kingdom (note 122 supra).

137 Johnston and Others $v$. Ireland (note 133 supra). 
Court, such as prospectivity of law, its foreseeability, clarity etc. The author of the article, former judge of the Lithuanian Constitutional Court and currently the judge of the European Court of Human Rights, examines how the latter court has gradually intensified (not always consistently) its reliance on the rule of law as a general principle, inherent in all the Articles of the European Convention on Human Rights, to the extent that in some of its judgments it concentrates not anymore on the factual situation of an individual applicant, but, first and foremost, on the examination of the quality of the law. The trend is that, having found the quality of the applicable law to be insufficient, the Court considers that the mere existence of contested legislation amounts to an unjustifiable interference into a respective right and finds a violation of respective provisions of the Convention. This is an indication of the Court's progressing self-approximation to constitutional courts, which are called to exercise abstract norm-control.

RESUMEN: La tradición occidental alumbró la noción del Estado de Derecho. La teoría del Derecho y la Justicia Constitucional han contribuido decisivamente a la cristalización de sus estándares, ayudando a conformar un acervo común en torno al mismo. El Tribunal Europeo de Derechos Humanos emplea la noción de Estado de Derecho como una herramienta interpretativa, fundamentalmente centrada en la doctrina de la calidad de la ley, que implica requisitos concretos que exige el Tribunal tales como la claridad, la previsibilidad, y la certeza en la redacción y aplicación de la norma. El autor, en la actualidad Juez del Tribunal Europeo de Derechos Humanos y anterior Magistrado del Tribunal Constitucional de Lituania, examina cómo el primero ha intensificado gradualmente (no siempre de forma igual de consistente) su confianza en el Estado de Derecho como principio general, inherente a todos los preceptos que forman el Convenio Europeo de Derechos Humanos, hasta el punto de que en algunas de sus resoluciones se concentra no tanto en la situación de becho del demandante individual sino, sobre todo y ante todo, en el examen de esa calidad de la ley. La tendencia del Tribunal es a considerar que, si observa que la ley no goza de calidad suficiente, la mera existencia de la legislación discutida supone una interferencia injustificable dentro del derecho en cuestión y declara la violación del precepto correspondiente del Convenio. Esto implica el acercamiento progresivo del Tribunal Europeo de Derechos Humanos a los Tribunales Constitucionales, quienes tienen encargado el control en abstracto de la norma legal.

KEY WORDS: Western legal tradition; the rule of law; human rights; European Convention on Human Rights; European Court of Human Rights; the quality of the law; constitutional courts.

Palabras Clave: Estado de Derecho, Tribunal Europeo de Derechos Humanos.

FECHA DE RECEPCIÓN: 29.06.2018 FECHA DE ACEPTACIÓN: 13.09.2018 
